\title{
Avkreft min galskap
}

\author{
Når man snakker om inkluderende \\ arbeidsliv, ligger vi kunstnere helt \\ i front. Om du er gal, deprimert, \\ alkoholiker eller psykopat: Her vil \\ ingen løfte på øyebrynet. Hos oss \\ glir du ubemerket inn i mengden.
}

Det er kanskje en spesiell type mennesker som trekkes mot kunstnerlivet. Urealistiske drømmere, notoriske melankolikere, folk som grubler for mye eller de som har i overkant god kontakt med følelsene sine. Så har du alle vokalistene. De fleste jeg har spilt med burde ikke under noen omstendigheter fylle ut Robert D. Hares verktøy for diagnostisering av psykopater. Samtidig er selve hverdagen vår egnet til å forvirre selv de mest normale av oss. Lite søvn, mye reising og et stort fravær av rutiner. Det finnes ingen HMS-ansvarlig i et band. Det tas ikke dopingkontroller på Herr Nilsen.

Alle kunstnere med respekt for seg selv merker derfor at galskapen iblant kjennes rett rundt hjørnet. Derfor var jeg egentlig ikke overrasket da det skjedde. Det var mer en bekreftelse på noe jeg ubevisst hadde ventet. Shanghai, 2005: Jeg bråvåkner av en høy lyd på hotellrommet og registrerer at gulvet beveger på seg og at veggene kommer nærmere. Det føles som en vond drøm, kroppen er meg fremmed, fingrene er numne, hjertet hamrer i brystet. Galskapen har gjort sin entré.

Den nyinntrufne galskapen - og dermed den kunstneriske autensiteten - gjorde meg dessverre verken mer genial eller produktiv. Derimot tok den raskt til å forsure livet mitt. Spesielt ble all reisingen et problem. Tidligere hadde turneringen vært det jeg elsket mest i livet. Nå ville jeg bare være hjemme. En klar ulempe for en turnerende musiker.

At jeg noen år senere havnet i kjelleren til psykiater Rolf Hess $\varnothing$, skulle vise seg å bli kanskje den viktigste tilfeldigheten i livet mitt. Jeg hadde sendt brev rundt på måfå i et etterhvert ganske fortvilet fors $\varnothing k$ på å få hjelp. At jeg havnet hos en ekspert på kognitiv terapi, var både heldig og tilfeldig. Hessø brukte 15 minutter på å forklare meg prinsippene bak panikkangst. Til min store overraskelse innså jeg at jeg ikke var gal likevel. Det var mildt sagt en lettelse.

Siden kom jeg stadig vekk i snakk med musikere og kolleger som hadde erfaringer med panikkangst. På en turné hadde jeg en særdeles livsglad og munter lokal sjåfør i bandbussen. Han hadde jobbet hele sitt liv med å frakte band rundt omkring i Europa, men en dag hadde han begynt å føle seg svimmel, forvirret og redd. Alt sammen uheldige egenskaper for en sjåfør. En dag eskalerte det, det var som om hjertet gikk amok, og han så ingen annen utvei enn å kjøre til sykehuset. Problemet var at han hadde et velkjent, internasjonalt band sittende i bussen sin. De skulle straks innfinne seg på en kjent konsertscene og var allerede altfor sent ute. Vår kjære sjåfør så imidlertid ikke annen løsning enn å råkjøre til sykehuset med bandet på slep. Det sto tross alt om livet.

På akuttavdelingen ble han heldigvis møtt av en lege som skjønte hva som var galt. Han fikk sette seg ned og puste i en pose, og da det verste hadde roet seg, dro han lykkelig videre. I lomma hadde han en henvisning til kognitiv terapi om han skulle trenge mer hjelp.

Etter å ha levd mesteparten av mitt voksne liv i hedonistisk svir gjorde jeg så for en gang skyld noe fornuftig. Høsten 2012 startet jeg nettstedet www.panikk.no, med god hjelp fra psykiater Hess $\varnothing$. Målet mitt var å forklare kolleger og venner i bransjen kortfattet og lett forståelig hva panikkangst var. Nå har vi hatt over 300000 treff, så det er visst ikke bare musikere og kunstnere som har behov for informasjon.

Mange som skriver til meg har sammensatte og ofte ganske elleville sykdomshistorier. Panikkangsten er ofte bare en del av hele bildet. Men det er en særdeles forstyrrende og ødeleggende del. Derfor er det viktig at fastlegene kan forklare pasientene hva panikkangst er, så de i hvert fall får et problem mindre å hanskes med.

Ufarliggjør fenomenet. Forklar om «fight or flight». Fortell hvorfor hjertet banker fortere, hvorfor man blir svimmel, hvorfor man blir kald på hendene. Og ikke minst: Fortell oss at vi ikke er gale.

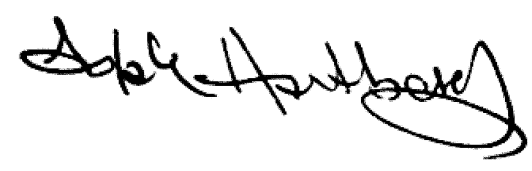

